\title{
The Quantitative
}

Determination of Calcite

Associated with

Carbonate-Bearing Apatites

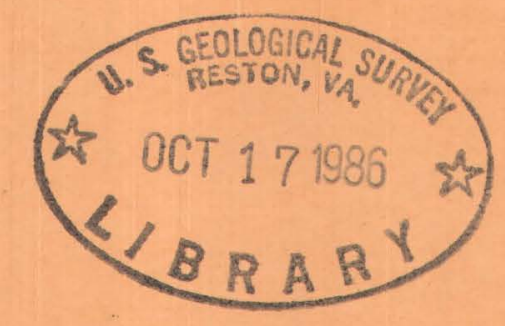

Trace Elements Investigations Report 118

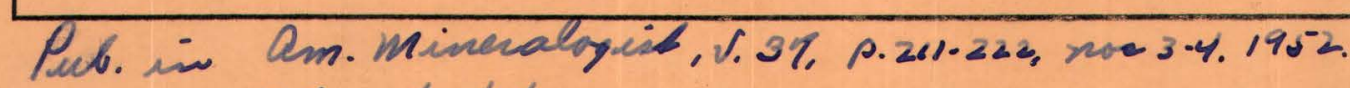
Open 7iled 10/19/5t.

UNITED STATES DEPARTMENT OF THE INTERIOR GEOLOGICAL SURVEY 
This Document consists of 26 pages Series A.

CATEGORY II-A (Mineralogy)

\section{UNITED STATES DEPARTMENT OF THE INTERIOR}

GEOLOGICAL SURVEY

Pub. in. Am. Mnieralogeit, V. 37 , nos. 3-4, p. 216-222. 1952 open tibed $10 / 19 / 51$.

THE QUANTITATIVE DETERMINATION OF CAICIIE ASSOCIATED WITH CARBONATE-BEARING APATITES

by

Sol R. Silverman, Ruth K. Fuyat, and Jeanne D. Weiser

August 1951

Trace Elements Investigations Report 118 
The distribution (Series A) of this report is as follows:

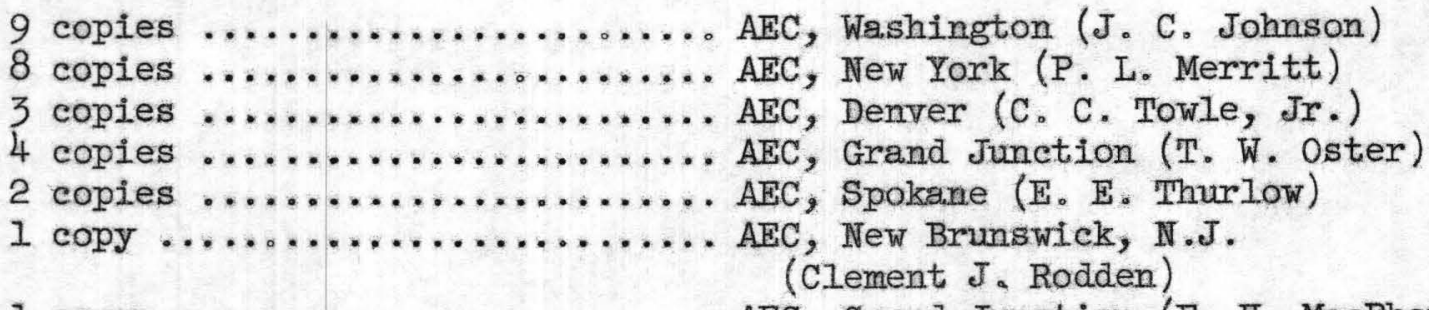

$I$ copy $\ldots \ldots \ldots \ldots \ldots \ldots \ldots \ldots \ldots$ AEC, Grand Junction (F. H. MacPherson)

1 copy $\ldots \ldots \ldots \ldots \ldots \ldots \ldots$ Homestake Mining Co., San Francisco (Donald H. Melaughlin)

1 copy .................... DeGolyer and McNaughton, Dallas

(Everette L. DeGolyer)

1 copy ................... Duluth (Thorold F. Field)

1 copy $\ldots \ldots \ldots \ldots \ldots \ldots \ldots \ldots \ldots \ldots$ M. A. Hanna Co., Cleveland (J. K. Gustafson)

1 copy $\ldots \ldots \ldots \ldots \ldots \ldots \ldots$. . . . . . Wulf Sulphur Co., New York (Wilber Judson)

1 copy .................... Oliver Iron Mining Co., Duluth (Walter I. Maxson)

1 copy ................... Temn. Coal, Iron and Railroad Co., Birmingham (Ernest H. Rose)

1 copy ................... Trojan Powder Co., Allentown (Walter 0. Snelling)

1 copy ................... Denver (Orvil R. Whitaker)

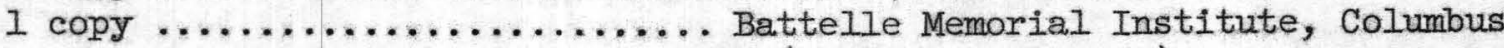
(Clyde E. Williams)

1 copy ....................... MIT, Cambridge (A. M. Gaudin)

1 copy ................... University of Minnesota, Minneapolis (J. W. Gruner)

1 copy ................... Columbia University, New York (Paul F. Kerr)

I copy $\ldots \ldots \ldots \ldots \ldots \ldots \ldots \ldots$ University of Wisconsin, Madison (R. C. Emmons)

1. copy .................. Harvard University, Cambridge (clifford Frondel)

$I$ copy ..................... MIT, Cambridge (Patrick Hurley)

1 copy ..................... American Museum of Natural History, New York (Frederick Pough)

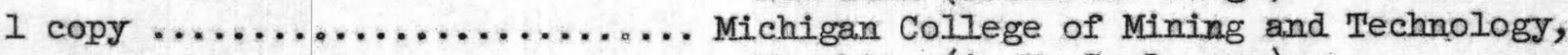
Houghton (A. K. Snelgrove)

1 copy ................... U. S. National Museum, Washington (George Switzer)

1 copy $\ldots \ldots \ldots \ldots \ldots \ldots \ldots \ldots . .$. Stanford University, Stanford (c. 0. Hutton) 


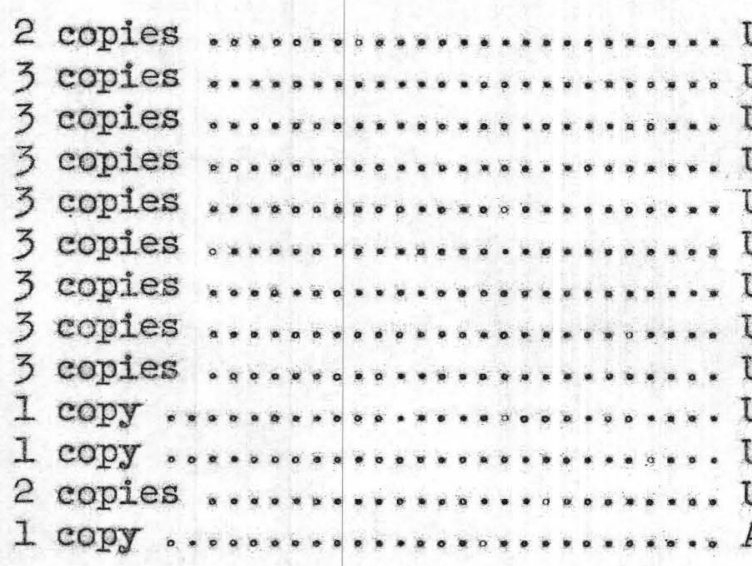

USBM, Washington (James Boyd)

USBM, Juneak, Alaska (S. H. Lorain)

USBM, San Francisco (Harold C. Miller)

USBM, Denver (John H. East)

USBM, Minneapolis (Parl Zinner)

USBM, ATbany, Oreg. (S. M. Shelton)

USBM, Pittsburgh (Harold P. Greenwald)

USBM, Norris, Tem. (Hewitt Wilson)

USBM, Amarillo, Tex. (C. W. Seibel)

USBM, Tueson (Bruce J. Clemmer)

USBM, Salt Lake City (S. R. Zimmerley)

USBM, Bluemont, Va. (Mitchell H, Kine)

Alaska Terr. Bur., Dept. Mines, Juneau

(Leo H. Saarela)

1 copy

Alaska Terr. Bur., Anchorage

(John J. O'Shea)

1 copy

Alaska Terr. Bur, College

(Donal. J. Cook)

1 copy

Alaska Terr. Cur , Ketchikan

(A. E. Glover)

1 eopy

Alaska Terr. Bur., Nome (Daniel A. Jones)

1 copy

Dow Chemical Co., Pittsburg, Calif.

(G. L. Allen)

1 copy

C \& CCD, $\mathrm{Y}-12$, Oak Ridge (Glenn Clewett)

1 copy American Cyanamid Co., Stamford, Conn.

(S. J. Swainson)

I copy American Smelting and Refining Co., Wallace, Idaho (Keith Whiting)

1 copy Anaconda Copper Co., Salt Iake City (Vincent Perry)

I copy Atchison Topeka and Santa Fe Railway Co., Chicago (S. G. Gurley)

$I$ copy Climax Molybdenum Co, New York (Lester A. Cowan)

$I$ copy.$\ldots \ldots \ldots \ldots \ldots \ldots \ldots$ Jones and Laughlin Steel Corp., Pittsburgh (L. P. Barrett)

1 copy $. . \ldots \ldots \ldots \ldots \ldots \ldots \ldots . . . \ldots$ Kennecott Co., New York (Anton Gray)

1 copy ....................... Molybdenum Corp. of America, New York (Marx Hirsch)

1 copy .................... Newmont Mining Co, New York (Fred Searls)

I eopy..$\ldots \ldots \ldots \ldots \ldots \ldots \ldots$. Sunshine Mining Co., Kellogg, Idaho (R. D. Leisk)

1 copy $\ldots \ldots \ldots \ldots \ldots \ldots \ldots \ldots$. U. S. Smelting and Refining Co.,

Salt Lake City (Richard Hunt)

1 copy U. S. Vanadium Corp., New York.

(A. P. Cortelyou)

1 copy African Metal Corp., New York (M. M. Bowman) 
1 copy ................... Galigher Co., Salt Lake City

(Harold E. Wright)

1 copy ................... Vanadium Corp. of America, New York

(William C. Keeley)

1 copy .................... Eldorado Mining and Refining (1944) Itd.

ottawa (William J. Bennett)

I copy ................... Idaho Bureau of Mines and Geology,

Moscow (A. W. Fahrenwald)

1 copy .................... Michigan State Dept. of Conservation,

Lansing (Franklin G. Pardee)

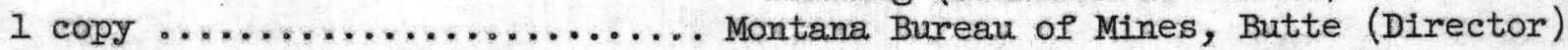

1 copy . . . . . . . . . . . . . . Nevada Bureau of Mines, Reno

(Jay A. Carpenter)

1 copy .................... usGS, Washington (Mineral Deposits Branch)

1 copy .................. USGS, Washington (Fuels Branch)

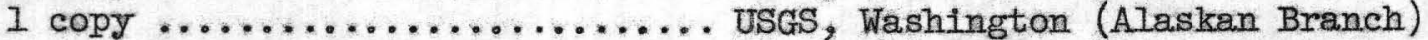

1 copy ................... USGS, Washington (Geophysics Branch)

14 copies .................. USGS, Wa.shington (Geochemistry and

Petrology Branch)

I copy ................... USGS, Washington (V. E. McKelvey)

1 copy ..................... usGs, Plant City, Fla. (J. B. Catheart)

1 copy ................... USGS, Denver ( $L$. R. Page)

$I$ copy .................... UsGS, Denver (J. F. Smith)

$I$ copy .................... USGS, Grand Junction (R. P. Fischer)

1 copy $\ldots \ldots \ldots \ldots \ldots \ldots \ldots \ldots \ldots$ USGS, Spokane (A. E. Weissenborn)

4 copies $. \ldots \ldots \ldots \ldots \ldots \ldots \ldots . \ldots . \ldots . \ldots$ USGS, Washington (TEPCO)

(including master copy) 
CONIENIS

Page

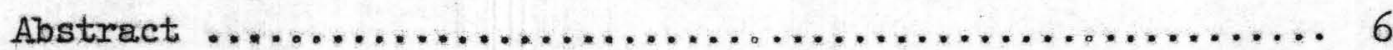

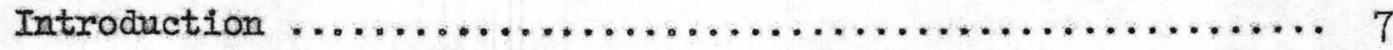

$\mathrm{X}$-ray analysis $\ldots \ldots \ldots \ldots \ldots \ldots \ldots \ldots \ldots \ldots \ldots \ldots \ldots \ldots \ldots \ldots \ldots \ldots, 8$

Differential thermal analysis $\ldots \ldots \ldots \ldots \ldots \ldots \ldots \ldots \ldots, 9$

Differential solubility tests $\ldots \ldots \ldots \ldots \ldots \ldots \ldots \ldots \ldots \ldots \ldots$. 12

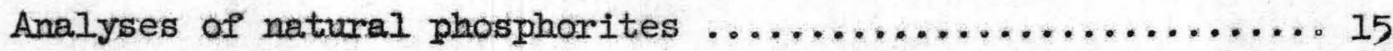

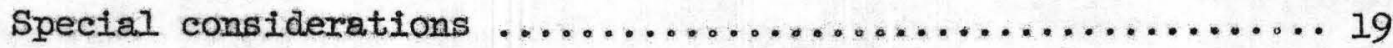

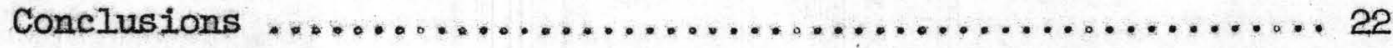

Appendix--Exposure of calcite obscured by

organic matter in phosphate rock $\ldots \ldots \ldots \ldots \ldots \ldots \ldots \ldots \ldots, 23$

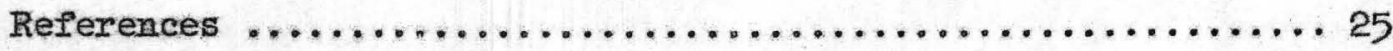

TABIES

Page

Table 1. Comparison of X-ray data $\ldots \ldots \ldots \ldots \ldots \ldots \ldots, 9$

2. Differential thermal data for artificial mixtures of calcium carbonate and fluorapatite...... II

3. Solubilities in $0.5 \mathrm{M}$ triammonium citrate solution .. 13

4. Carbon dioxide content of phosphorites ........... 15

5. Comparison of results obtained by solubility, differential thermal, and X-ray methods on natural phosphate materials

6. Carbon dioxide content of residues of samples 150 and 162 after leaching for various lengths of time $\ldots \ldots \ldots \ldots \ldots \ldots \ldots \ldots \ldots . .19$

7. Relative surface areas for different particle sizes of carbonate-fluorapatite ................ 2l 
THE QUANTITATIVE DETERRIVATION OF CALCITE ASSOCIATTED

WITH CARBONATIE-BEARING APATITES

\author{
by \\ Sol R. Silverman, Ruth K. Fuyat, \\ and Jeanne $\mathrm{D}$. Wetser
}

\begin{abstract}
The $\mathrm{CO}_{2}$ combined as calcite in carbonate-bearing apatites has been distinguished from that combined as carbonate-apatite, or present in some form other than calcite, by use of X-ray powder patterns, differential thermal analyses, and differential solubility tests. These methods were applied to several pure apatite minerals, to one fossil bone, and to a group of phosphorites from the Phosphoria formation of Permian age from Trail Canyon and the Conda mine, Idaho, and the Laketown district, Utah. With the exceptions of pure fluorapatite, pure carbonate-fluorapatite, the fossil bone, and one phosphorite from Trail Canyon, these substances contain varying amounts of calcite, but in all the samples an appreciable part of the carbonate content is not present as calcite. The results of solubility tests, in which the particle size of sample and the length of solution time were varied, imply that the carbonate content is not due to shielded calcite entrapped along an internal network of surfaces.
\end{abstract}




\section{INIRODUCTION}

The existence of carbonate-apatite as a distinct mineral constituent of bone, teeth, and phosphorite is not universally accepted. Hendricks and Hill (1950, pp. 731-737) attribute the carbonate content of bone and of all carbonate-bearing apatites to carbonate entrapped in hydroxylapatite or in hydrated tricalcium phosphate. Other workers (Dallemagne, Brasseur, and Mélon, 1949, pp. 138-145; Dallemagne and Mélon, 1945, pp. 597-599) claim that bone is a mixture of tricalcium phosphate and calcium carbonate, but they do not question the existence of carbonate-apatite as a distinct mineral phase in dentine. McConnell and Gruner (1940, pp. 157-167) recognize carbonate-apatite as a single homogeneous mineral. The controversy has been summarized by Geiger (1950, pp. 161-181).

Staining methods (see appendix) have indicated that an appreciable part of the carbonate content of natural phosphorites is present as calcite. In order to determine quantitatively the amounts of carbonate present as calcite and as carbonate not combined as calcite, carbonate-bearing phosphorites were examined by three independent methods: $\mathrm{X}$-ray analysis, differential thermal analysis, and differential solubility tests.

This work was completed as part of a program undertaken by the U. $\mathrm{S}$. Geological Survey on behalf of the Atomic Energy Commission.

The writers are indebted to their associates at the U. S. Geological Survey for technical assistance--to Henry Mela, Jr., I. Barlow, and A. M. Sherwood for the carbon dioxide analyses; to E. A. Cisney, who prepared the X-ray films; and to Z. S. Altschuler, C. I. Christ, G. T. Faust, E. Ingerson, and Elizabeth B. Jaffe, who read the manuscript and made valuable suggestions. 


\section{X-RAY ANALYSIS}

Optically homogeneous apatites containing as much as 5.8 percent carbon dioxide have been reported. Whether the carbon dioxide is present as calcite or as carbonate in some other form or is integrated in the apatite structure, these substances would be expected to give X-ray patterns distinguishable from those of carbonate-free apatites. In 1933 Bredig, Franck, and Füldner (1933, pp. 959-969) reported having recognized distinct differences in the X-ray diffraction pattern of a carbonate-hydroxylapatite as compared with those of fluorapatite and hydroxylapatite. The controversy that followed is reflected in the work of Thewlis, Glock, and Murray (1939, pp. 358-363), and McConnell and Gruner (1940, pp. 157-167).

Small but measurable differences in the X-ray patterns of carbonatefluorapatite, hydroxylapatite, and fluorapatite have been detected in the course of this investigation, and a complete account of these differences will be published later. The distinction is based on variations in spacings between the (23I) and (004) lines in X-ray powder films exposed on a 57.3-mm radius camera using nickel-filtered copper radiation.

The variations of X-ray data listed in table 1 were obtained from two hydroxylapatites (from Holly Springs, Ga., and a synthetic product prepared by W. L. Hill of the U. S. Department of Agriculture), from two fluorapatites (from Cerro Mercado, Durango, Mexico, and Ontario, Canada), and from two carbonate-fluorapatites ("staffelite" from Staffel, Germany, and "francolite" from Cornwall, England). 
Table 1.--Comparison of X-ray data

\begin{tabular}{|c|c|c|c|c|}
\hline & $\begin{array}{l}\text { Plane } \\
\text { indices }\end{array}$ & $\begin{array}{c}2 \theta \\
(\mathrm{mm})\end{array}$ & $\begin{array}{c}\text { d-spacings } \\
\text { (A) }\end{array}$ & $\underset{(\mathrm{mm})}{\Delta 1 / 1}$ \\
\hline Hydroxylapatite & $\begin{array}{l}231 \\
004\end{array}$ & $\begin{array}{l}50.6 \\
53.3\end{array}$ & $\left.\begin{array}{l}1.804 \\
1.719\end{array}\right\}$ & 2.7 \\
\hline Fluorapatite & $\begin{array}{l}231 \\
004\end{array}$ & $\begin{array}{l}50.8 \\
53.3\end{array}$ & $\left.\begin{array}{l}1.797 \\
1.719\end{array}\right\}$ & 2.5 \\
\hline Carbonate-fluorapatite & $\begin{array}{l}231 \\
004\end{array}$ & $\begin{array}{l}50.9 \\
53.2\end{array}$ & $\left.\begin{array}{l}1.794 \\
1.722\end{array}\right\}$ & 2.3 \\
\hline I/ Difference bet & een $2 \theta$-ve & (in $\mathrm{mm}$ ) & for lines (231) & and $(004)$ \\
\hline
\end{tabular}

The presence of calcite in artificial calcite-apatite mixtures was readily discernible. Powder films were taken of mixtures of a pure fluorapatite from Durango and chemically pure calcium carbonate, with the latter present in proportions of $2,3,4,5,7$, and 10 percent by welght. The X-ray pattern of the mixture containing 2 percent calcium carbonate was indistinguishable from that of pure fluorapatite. Three characteristic calcite lines (d-values of $3.038 \mathrm{~A}, 2.089 \mathrm{~A}$, and $1.914 \mathrm{~A}$ ) were identified in each of the remaining mixtures. The presence of calcite in amounts of 3 percent and above is thus detectable in artificial mixtures by use of the X-ray method described.

\section{DIFFERENTIAL THERMAL ANALYSIS}

It is unlikely that carbonate would be held by identical bonding forces in both calcite and carbonate-apatite. Consequently the heat and temperature of decomposition of calcite should differ from those of carbonate-apatite. These properties are conveniently measured by means 
of a differential thermal analysis apparatus. The theoretical and operational details of this apparatus have been described by Hendricks, Goldich, and Nelson (1946, pp. 64-76)

The following investigations were performed on a portable field unit I/ that was rewired for use with platinum-platinum (90\%), rhodium (10\%) thermocouples.

Reference curves were prepared from the thermal data for chemically pure calcium carbonate, calcite, fluorapatite, carbonate-fluroapatite, and artificial mixtures of a pure natural fluorapatite and $2,5,7$, and 10 percent chemically pure calcium carbonate. The sharp and abrupt endothermic peaks resulting from the thermal decomposition of both natural calcite and chemically pure calcium carbonate are comparable to those reported in the literature (Cuthbert and Rowland, 1947, p. 113; Faust, 1950, p. 217). Fluorapatite alone gives a smooth curve when heated to $950^{\circ} \mathrm{C}$. The carbonate-fluorapatite, an optically homogeneous mineral from Staffel, Germany, containing 3.1 percent $\mathrm{CO}_{2}$, which is equivalent to 7 percent $\mathrm{CaCO}_{3}$, did not show the distinct endothermic peak typical of calcite. Instead it gave a smooth curve, which, in relation to the fluorapatite curve, suggests a very gentle endothermic trend over the entire temperature range. These observations are in agreement with the heat-loss data reported by Geiger (1950, pp. 168, 178).

Each of the artificial mixtures of ealcium carbonate and fluorapatite gave a calcite peak superimposed on the smooth fluorapatite curve. The

If Designed by R. A. Nelson of the U. S. Geological Survey, and manufactured by the Fberbach and Son Co., Ann Arbor, Mich. 
relative heights and breadths of peaks for the different mixtures are presented in table 2. The relative areas included under the calcite peaks, which were measured with a polar planimeter, are roughly proportional to the amounts of calcium carbonate present. The corresponding variations of peak temperatures with amount of calcium carbonate present are due primarily to differences in the partial pressures of the $\mathrm{CO}_{2}$ liberated during the early stages of thermal decomposition (Rowland and Lewis, 1951, pp. 86-87).

Table 2.--Differential thermal data for artificial mixtures of calcium carbonate and fluorapatite

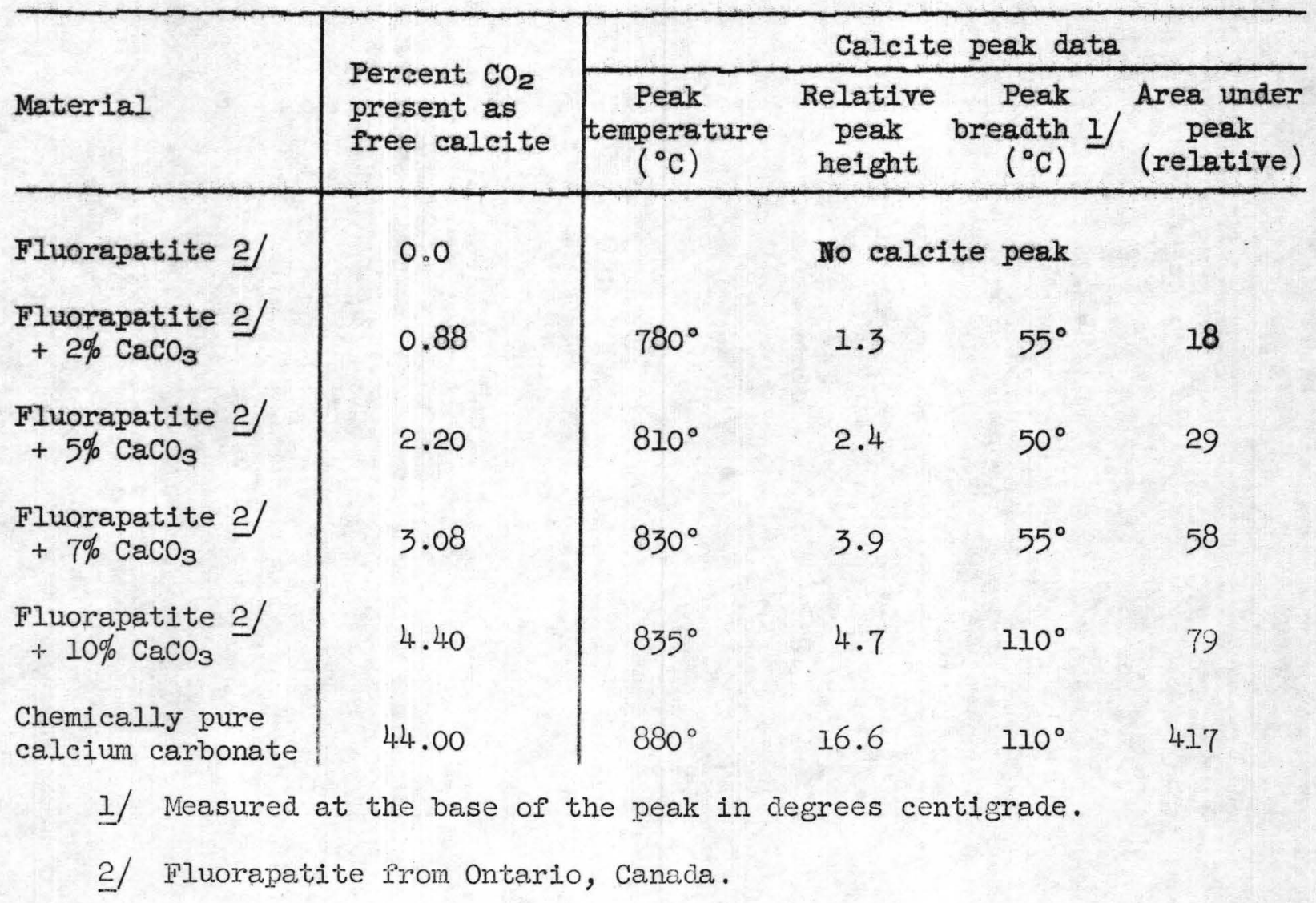


In order to check the validity of the results, G. T. Faust was kind enough to run pure fluorapatite, carbonate-fluorapatite, and the mixture of fluorapatite and 2 percent calcium carbonate on a more sensitive differential thermal unit (Faust, 1948, pp. 337-345). The curves obtained with our portable field unit compared favorably with those from the more precise instrument, and we ascertained that the portable unit could be depended upon to detect a minimum of 1.6 percent calcite in natural phosphates.

\section{DIFFERENTIAL SOLUBILITY TEESTS}

Differential solubility methods have been applied successfully in the past to the separation of the components of a mixture. The carbonateapatite problem is principally one of distinguishing a homogeneous from a heterogeneous mineral composition. The applicability of differential solubility tests to this problem depends on the existence of a solvent in which carbonate-apatite is relatively insoluble as compared with calcite.

A solvent that fulfills this requirement is a half-molar aqueous solution of triammonium citrate. The solubility of calcite in this solvent has been established by Rindell (1910, pp. 452-458).

The data in table 3 indicate that calcium carbonate is approximately 50 times as soluble as either fluorapatite or carbonate-fluorapatite in this reagent.

The triammonium citrate solution was prepared by titration of chemically pure diamonium citrate with ammonium hydroxide to $\mathrm{pH}$ of $8.1 \pm 0.1$. 
The solubility values in table 3 were determined by the addition of $100 \mathrm{ml}$ of solvent to $1 \mathrm{~g}$ of powdered sample (ground to pass 200 mesh) in a glassstoppered Erlenmeyer flask. The mixture was permitted to stand for 24 hours at room temperature, with intermittent shaking, after which it was filtered and the filtrate ignited to constant weight. The solubility of pure calcium carbonate was computed from the weight of the ignited product (calcium oxide).

Table 3.--Solubilities in $0.5 \mathrm{M}$ triammonium citrate solution

Material

Solubility

in grams/100 ml solvent

Calcium carbonate, $\mathrm{cp}$

$0.660 \mathrm{~g} \pm 0.060$

Fluorapatite, Durango, Mexico

$0.014 \mathrm{~g} \pm 0.000$

Carbonate-fluorapatite,

Staffel, Germany

$0.012 \mathrm{~g} \pm 0.003$

Geiger's heat-loss data (1950, p. 168) indicate that "staffelite" loses at least 65 percent of its $\mathrm{CO}_{2}$ content by ignition to $900^{\circ} \mathrm{C}$. The carbonate-fluorapatite solubility value given in table 3, however, required no correction for $\mathrm{CO}_{2}$ lost during igntion as the maximum possible loss is less than $0.0004 \mathrm{~g}$, which is beyond the limiting precision of the measurements.

On the basis of solubility values obtained by 48 - and 72 -hour treatments, which were identical with the solubility values obtained in 24 hours (see table 6), it was concluded that any discrepancies due to incomplete solution were not large enough to invalidate the conclusions reached by 
these measurements. In Rindell's original work (1910, pp. 452-458), it was assumed that equilibrium is attained in 24 hours.

The relatively high limits of error reported in table 3 were undoubtedly due to the lack of precisely controlled conditions. The precision of these measurements can be improved by use of a controlled-temperature bath, of a constant stirring mechanism, and by very precise standardization of the solvent. The degree of precision attained, however, was sufficient for the immediate purposes of these investigations.

The calcite content of each phosphorite was determined by treating each 1-g sample with $100 \mathrm{ml}$ of solvent in the manner described for the solubility measurements. After the mixture was filtered the insoluble residue was washed with distilled water. The dried insoluble residue and the original sample were analyzed gravimetrically for carbanate contert by absorption of carbon dioxide in ascarite (Kolthoff and Sandell, 1948, pp. 385-389) after liberation of the carbon dioxide by dilute hydrochlorf.c acid. The difference between the carbon dioxide content of the original sample and that of the leached residue was taken as a measure of carbon dioxide present as calcite. The results of the absorption method are reproducible to $1 \mathrm{mg}$; the carbon dioxide content for $1 \mathrm{~g}$ of sample is theretore reliable to 0.1 percent.

In order to establish the effectiveness of the solvent on calcite in the presence of apatite, artificial mixtures of the Durango fluorapatite containing $2,5,7$, and 10 percent of chemically pure calcium carbonate were treated with the solvent. In each of these check determinations the insoluble residues were found to be entirely free of calcite within the limits of error. 


\section{ANALYSES OF NATURAL PHOSPHORITES}

These methods, whose reliabilities have been established for artificial mixtures and pure end members, were then applied to natural phosphorites.

Samples were selected from the phosphatic shale member of the Phosphoria formation (Idaho and Utah) on the basis of their carbonate content, as shown in table 4 .

Table 4.--Carbon dioxide content of phosphorites

\begin{tabular}{|c|c|c|c|c|}
\hline \multicolumn{2}{|c|}{ With visible calcite } & \multicolumn{3}{|c|}{ Without visible calcite } \\
\hline Sample no. & $\begin{array}{l}\text { content } \\
\text { rcent) }\end{array}$ & Sample no. & & $\begin{array}{l}\text { ontent } \\
\text { cent) }\end{array}$ \\
\hline $\begin{array}{l}150 \text { (Conda mine, Idaho) } \\
163 \text { (Conda mine, Idaho) } \\
161 \text { (Conda mine, Idaho) } \\
\text { 164B (Conda mine, Idaho) } \\
1007-1 \text { (Laketown, Utah) } \\
\text { 164A (Conda mine, Idaho) } \\
1007-7 \text { (Laketown, Utah) }\end{array}$ & $\begin{array}{l}4.7 \\
4.5 \\
3.1 \\
2.5 \\
1.8 \\
1.4 \\
1.4\end{array}$ & $\begin{array}{l}\text { 311C (Trail Canyon, } \\
309 \text { (Trail Canyon, } \\
317 \text { (Trail Canyon, } \\
300 \text { (Trail Canyon, } \\
\text { 315B(Trail Canyon, }\end{array}$ & $\begin{array}{l}\text { Idaho) } \\
\text { Idaho) } \\
\text { Idaho) } \\
\text { Idaho) } \\
\text { Idaho) }\end{array}$ & $\begin{array}{l}1.9 \\
1.6 \\
1.3 \\
1.2 \\
1.1\end{array}$ \\
\hline
\end{tabular}

In addition, a fossil rib bone (genus Felsinotherium) of probable early Pliocene age (sample 74-M-4) from the Boyette mine, Hillsborough County, Fla., was included in these analyses.

A compilation of the results obtained by the three methods appears in table 5. The samples are arranged in the order of increasing calcite content as determined by the solubility method (column 3 ).

The differential thermal data in columins 4 and 5 show an orderly progression of increasing temperatures and endothermic peak heights with 
Table 5.--Comparison of results obtained by solubility, differential thermal, and $\mathrm{X}$-ray methods on natural phosphate materials

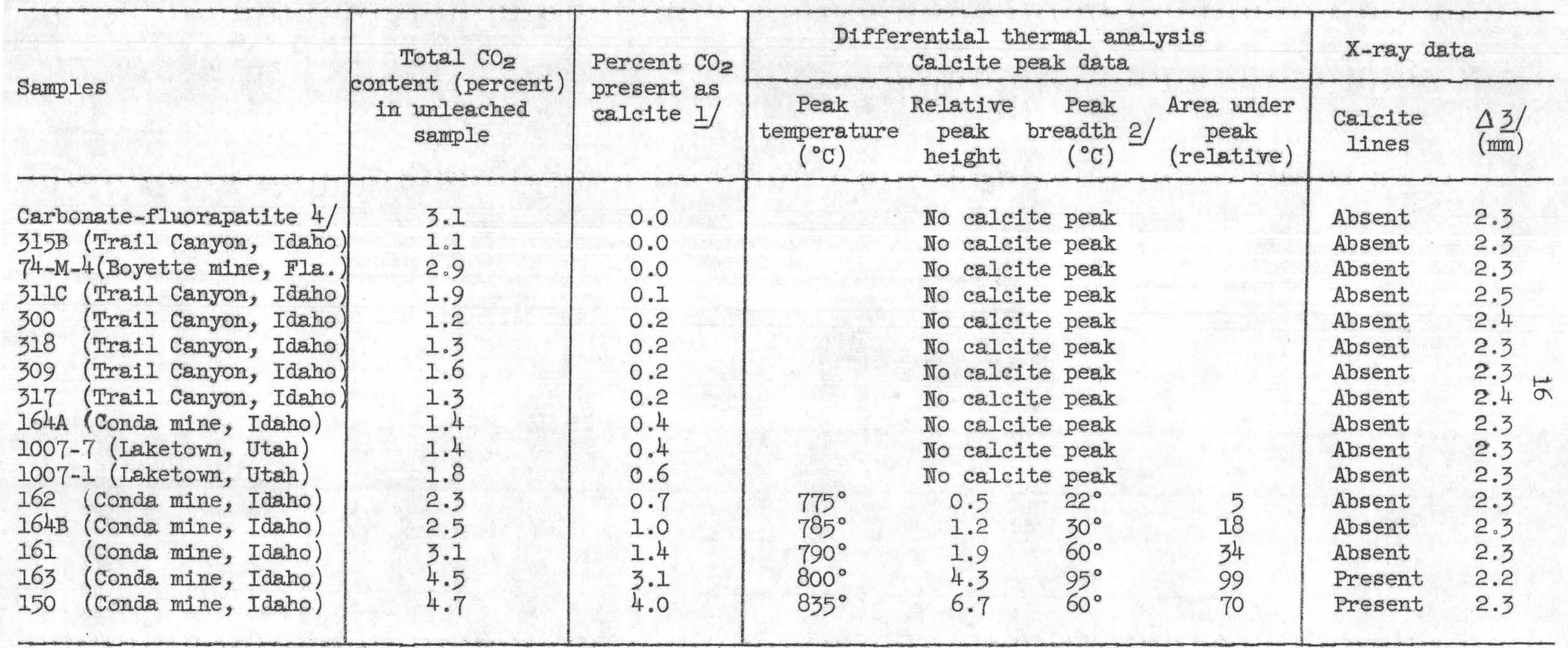

I/ Results of trianmonium citrate solubility tests.

2 Measured at the base of the peak in degrees centigrade.

3) Difference between $2 \theta$-values (in $\mathrm{mm}$ ) for lines (231) and (004).

4) From Staffel, Germany. 
increasing calcite content for the samples containing more than 0.7 percent $\mathrm{CO}_{2}$ combined as calcite.

In addition to calcite, the phosphorites contain small but varying amounts of thermally active substances, chiefly clays, organic matter, and iron oxides. Of these materials, certain clays may undergo thermal changes in the temperature region of the calcite decomposition, thereby interfering with the endothermic peak due to calcite alone. For most of the materials examined, this interference was not great enough to cause a serious discrepancy in the calcite peak measurements. Of the group of samples in table 5, sample 163 has the lowest phosphate content; accordingly the relative proportions of foreign materials is greater; and the contaminating substances have interfered by causing a broadening of the calcite peak at its base, which has resulted in an abnormally large area under the peak. Where the above-mentioned thermally active substances are comparatively negligible, as in sample 150, where they are essentially absent, the resulting thermal curves are almost identical with those obtained from the artificial calcite-apatite mixtures.

The presence or absence of the three calcite lines in X-ray powder films (table 5, column 8) depends to a certain extent on the quality of the pattern. The artificial mixture of fluorapatite and 3 percent calcium carbonate gave a sharp pattern in which the calcite lines could be detected. Sample 16I, a phosphorite that contains $3.2 \pm 0.2$ percent calcite as determined by the solubility tests, gave a less distinct pattern in which the calcite lines were not visible. The X-ray pattern obtained from sample 163, a phosphorite containing $7.0 \pm 0.2$ percent calcite, showed the same poor 
definition and high background intensity as that obtained from sample 161 , but in this case the calcite lines were detectable.

The last column lists the differences between the $2 \theta$-values for lines (231) and (004) referred to in table 1.

Samples from the Conda mine in southeast Idaho are unweathered, black, and dense, whereas those from the nearby outcrop at Trail Canyon are weathered, brown, and less consolidated. Both groups of samples are from equivalent parts of the Phosphoria formation. This correlation is based on the distinctive character of a single bed of brecciated nodules of phosphatized palaeoniscoid fish scales and small coprolitic masses (?) Identified by D. H. Dunkle, of the U. S. National Museum. At the Conda mine (sample 150) this bed contains 4.1 percent of free calcite, whereas at Trail Canyon (sample 300) the calcite content is negligible. The characteristically low calcite content of the Trail Canyon samples as compared to that from the Conda mine is probably due to natural leaching processes. The other samples from Trail Canyon and the Conda mine are "pelletal phosphorites" typical of the phosphatic shale member of the Phosphoria formation in southeast Idaho.

AIl samples contain at least 75 percent apatite. The average organic content of the Conda mine samples is higher than that of the Trail Canyon samples by about 3 percent. The samples from the Laketown district, Utah, are sieve fractions of one bed that contains visible calcite, detrital material, and secondary clays but is devoid of organic matter. 


\section{SPECIAL CONSIDERATIONS}

Hendricks and Hill (1950, p. 737) have concluded from investigations of the mineral constituents of bone that "carbonate is present on entrapped surfaces and not as constituent within the lattice of the mineral francolite, the typical 'carbonate apatite'..." If the carbonate present in these samples is present as calcite entrapped at crystallite boundaries it is possible that some part of the included calcite would not be accessible to the solvent. The following experiments were designed to test the availability of calcite occluded along a continuous, as well as along a discontinuous, network of surfaces.

Two samples, 150 (Conda) and 162 (Conda), containing 4.7 percent and 2.3 percent $\mathrm{CO}_{2}$, respectively, were treated with the solvent, a half-molar solution of triammonium citrate, for 24,48 , and 72 hours. The carbon dioxide content of the leached residues was essentially constant, as shown in table 6.

Table 6.--Carbon dioxide content of residues of samples 150 and 162 after leaching for various lengths of time

$\begin{array}{llll}150 \text { (Conda mine) } & 0.9 \pm 0.0 & 0.9 \pm 0.0 & 0.9 \pm 0.0 \\ 162 \text { (Conda mine) } & 1.6 \pm 0.1 & 1.6 \pm 0.0 & 1.5 \pm 0.1\end{array}$

These results indicate that equilibrium between the solid phases, consisting mainly of apatite, and the liquid phase, containing dissolved 
calcium carbonate, dissolved apatite, and solvent is established after 24 hours. Preliminary solubility measurements (table 3) show that $100 \mathrm{ml}$ of solvent, saturated with apatite, can dissolve more than $0.6 \mathrm{~g}$ of calcium carbonate. One-gram samples of 150 and 162 contain sufficient carbon dioxide to account for $0.11 \mathrm{~g}$ and $0.05 \mathrm{~g}$ of calcium carbonate, respectively. The liquid phase in a mixture of $1 \mathrm{~g}$ of either of these materials and $100 \mathrm{ml}$ of solvent, in equilibrium with the solid phase, is unsaturated with respect to $\mathrm{CaCO}_{3}$. Under these conditions no solid. calcium carbonate should exist in contact with the liquid.

If the carbonate is restricted to a continuous network of calcite along entrapped surfaces, the calcite would be accessible to the solvent only at the points where the network was exposed at the surface of the particle. Under these conditions the amount of calcite dissolved by the solvent should vary with the length of time. The absence of such variation (table 6 ) is evidence against a continuous network of occluded calcite.

Additional evidence comes from a study of the relation of the solubility of carbonate-apatite to particle size. The carbonate-fluorapatite, an optically homogeneous mineral from Staffel, Germany, contains 3.1 percent $\mathrm{CO}_{2}$, which is equivalent to about 7 percent calcium carbonate. The solubility measurements (table 5) indicate that no calcium carbonate is present. The carbonate content is therefore present as a constituent of the apatite structure, or as some other form of carbonate that is not combined as calcite. Three sieve fractions $(+60-84,+165-200$, and $+325-400$ ) of this mineral were treated with the solvent for 24 hours. 
The relative surface areas per given weight of material have been computed for each sieve size. These computations, which take into account the columnar shape of the fragments (length of columns are approximately twice their width), give the values listed in table 7 .

Table 7.--Relative surface areas for different particle sizes of carbonate-fluorapatite

$\begin{array}{rrr}+60 & -84 & 1.00 \\ +165 & -200 & 2.86 \\ +325 & -400 & 6.44\end{array}$

In each size fraction no difference in the $\mathrm{CO}_{2}$ content of the leached residue as compared with that of the unleached material was detectable within the limits of measurement.

The volume of a single particle of the smallest size group (+325 -400 mesh) is $1.3 \times 10^{-7} \mathrm{~cm}^{3}$, and it represents more than a sixfold increase in surface area per unit weight of material over that of the coarsest group ( $+60-84$ mesh). Regardless of the dimensions of "entrapped" calcite, if the 3.1 percent $\mathrm{CO}_{2}$ content of this carbonate-fluorapatite is present as calcite, the calcite must occupy 9.2 percent of the total volume. To the extent of the increase in surface area represented by the difference between the coarsest and finest particle sizes considered here, the experimental observations constitute an argument against occluded calcite along a discontinuous network. Furthermore, if any carbonate is 
present as occluded calcite, its distribution in this mineral must be random. The solubility relations of this mineral to half-molar triammonium citrate solution are generally those expected from a single, very slightly soluble, homogeneous compound.

\section{CONCLUSIONS}

The presence of calcite in carbonate-bearing phosphorites has been determined by use of X-ray methods, differential thermal analyses, and solubility tests. The minimal detectable amounts of calcite, as shown by the results in table 5 , are 7.0 percent, 1.6 percent, and 0.1 percent, respectively, for the above methods.

Application of these procedures leads to the conclusions that in some samples (carbonate-fluorapatite from Staffel, Germany; 74-M-4; and 315B, Trail Canyon) no part of the $\mathrm{CO}_{2}$ content, which ranges from 3.1 to 1.1 percent, is present as calcite. The other phosphorites examined in this survey contain variable amounts of calcite, but in all of them an appreciable part of the carbonate is not present in the form of calcite.

The results of solubility tests, in which the particle size of sample and the length of solution time were varied, imply that the carbonate content is not due to shielded calcite entrapped along continuous or discontinuous surfaces. 


\section{APPENDIX}

Exposure of calcite obscured by organic matter in phosphate rock

$$
\text { by }
$$

Jeanne D. Weiser

Small amounts of calcite in some samples of phosphate rock from southeastern Idaho are often concealed in thin sections or powder mounts by the high content of organic matter, and no clue to the presence of the calcite is offered by chemical analysis for total $\mathrm{CO}_{2}$ because the major mineral constituent is a carbonate-bearing apatite. By the slight modification and combination of two well-known petrographic techniques, the presence and distribution of calcite and the reason for $i$ ts obscurity were made clear.

Rectangular blocks 1 1/2 inches by 1 inch by 1 inch of black phosphatic rock were cut and placed in small porcelain crucibles so that the blocks were resting only on corners and edges. They were then placed in a Tempeo Electric Furnace and heated through three temperature stages as follows: I hour with the temperature control set at "low" (from room temperature to $200^{\circ} \mathrm{C}$ ), I I/2 hours at "medium" (from $200^{\circ} \mathrm{C}$ to $425^{\circ} \mathrm{C}$ ), and $11 / 2$ hours at "high" (from $425^{\circ} \mathrm{C}$ to $775^{\circ} \mathrm{C}$ ). At the end of this time the blocks turned white.

Slow and gradual heating prevented the samples from decrepitating because of sudden loss of water, and keeping the temperature below $800^{\circ} \mathrm{C}$ 
avoided any appreciable destruction of the calcite. It is possible that calcite near the outer surfaces of the blocks calcines at this temperature, as the dissociation meets progressively less interference nearer the surface.

Uncovered thin sections were prepared from the blocks roasted in this manner and then were stained by the silver nitrate-potassium chromate method described by Krumbein and Pettijohn (1938, p. 496).

The thin sections turned a grayish orange pink (5YR 7/2), a color that can be resolved by means of the petrographic microscope into microscopic spots of reddish-brown calcite fairly evenly distributed throughout the cryptocrystalline phosphate pellets.

When these factors concerning the calcite are considered, that is, its relative paucity compared with the organic matter, its small size, and even distribution, it is understandable that more than 2 percent of this highly birefringent mineral could be rendered invisible.

The precise quantitative method for the detection of calcite in the presence of carbonate-bearing apatite, described in the main body of this report, was subsequently developed so that the chief value of this experiment now lies in exposing the distribution of calcite hitherto hidden by organic matter in phosphate rocks. It is also reassuring to observe that the silver nitrate-potassium chromate method of staining will operate on particles of very small size. 
REFERENCES

Bredig, M. A., Franck, H. H., and Füldner, H., 1933, Beiträge zur Kenntnis der Kalk-Phosphorsaure Verbindungen: Zeitschr. Elektrochemie, vol. 39, pp. 959-969.

Cuthbert, F. I., and Rowland, R. A., 1947, Differential thermal analysis of some carbonate minerals: Am. Mineralogist, vol. 32, pp. 111-116.

Dallemagne, M. J., and Mélon, J., 1945, La formation de brushite à partir des sels osseux ou dentaires: Bull. soc. chim. biol., vol. 27, pp. 597599.

Dallemagne, M. J., Brasseur, H., and Mélon, J., 1949, La constitution de la substance minerale de $I^{\prime}$ os et la synthèse des apatites: Soc. chim. France Bull., fasc. 3-4, pp. 138-145.

Faust, George T., 1948, Thermal analysis of quartz and its use in calibration in thermal analysis studies: Am. Mineralogist, vol. 33, pp. $337-345$.

1950, Thermal analysis studies on carbonates. I. Aragonite and calcite: Am. Mineralogist, vol. 35, pp. 207-224.

Geiger, Th., 1950, Beiträge zum Problem der Karbonatapatite: Schweizer. min. pet. Mitt., vol. 30 , pp. 161-181.

Hendricks, S. B , Goldich, S. S., and Nelson, R. A., 1946, A portable differential thermal analysis unit for bauxite exploration: Econ. Geology, vol. 41, pp. 64-76.

Hendricks, S. B., and Hill, W. L., 1950, The nature of bone and phosphate rock: Nat. Acad. Sci. Proc., vol. 36, pp. 731-737.

Kolthoff, I. M., and Sandell, E. B., 1948, Textbook of quantitative inorganic analysis, revised edition, $794 \mathrm{pp}$., New York, Macmillan Co.

Krumbein, W. C., and Pettijohn, F. J, 1938, Manual of sedimentary petrography, 549 pp., New York, D. Appleton-Century Co.

McConne11, Duncan, and Gruner, John W., 1940, The problem of the carbonateapatites. III. Carbonate-apatite from Magnet Cove, Arkansas: Am. Mineralogist, vol. 25, pp. 157-167.

Rinde11, A., 1910, Über das Verhalten schwerlöslicher Calciumsalze zu wässerigen Lösungen von Ammoniumsalzen, besonders derjenigen von Triammonium citrat: Zeitschr. physikal. Chemie, vol. 70 , pp. $452-458$. 
Rowland, Rlchards A., and Lewis, Donald R., 1951, Furnace atmosphere control in differential thermal analysis: Am. Mineralogist, vol. 36 , pp. 80-91.

Thewlis, J., Glock, G. E., and Murray, M. M., 1939, Chemical and X-ray analysis of dental, mineral, and synthetic apatites: Faraday soc. Trans., vol. 35, pp. 358-363. 